\author{
Anna Hurajová ${ }^{1}$ \\ University of Ss. Cyril and Methodius in Trnava
}

\title{
Czech and Slovak bilingualism in the media ${ }^{2}$
}

\begin{abstract}
The article deals with the specific cultural and language relations between the Czech Republic and the Slovak Republic. It especially focuses on the interlingual relations between the two states, taking into account the peculiarities of Czech-Slovak bilingualism in the media against the background of the social changes after the split of Czechoslovakia. The distinction between bilingualism and semi-communication is explained. Attention is paid to interlingual relations, especially the presence of perceptive bilingualism, the divergence of the two languages, the cultural exchange between the two nations, and the status of the Slovak language in the Czech media environment - namely its presence on TV, the radio, in the press and in cultural life in general.
\end{abstract}

Keywords: bilingualism, semi-communication, Czech-Slovak bilingualism, language contact, media.

\section{Czesko-słowacka dwujęzyczność w mediach}

\section{Streszczenie}

W artykule opisano specyficzne relacje kulturowe i językowe między Republiką Czeską a Republiką Słowacką. W szczególności autorka koncentruje się na relacjach międzyludzkich między tymi dwoma państwami, biorąc pod uwagę specyfikę czesko-słowackiej duujęzyczności w mediach na tle zmian społecznych po rozpadzie Czechosłowacji. Rozróżnia duujęzyczność i semikomunikację. Ponadto zuraca uwagę na stosunki międzyjęzykowe, szczególnie na obecność duujęzyczności pasywnej, rozbieżności między dwoma językami, uymiany kulturowej między tymi dwoma narodami oraz na status języka słowackiego w czeskim środowisku medialnym, tj. obecność u telewizji, radiu, w prasie i ogólnie w życiu kulturalnym. Tekst przygotowano w ramach projektu badawczego wspieranego przez Agencję Grantową Ministerstua Edukacji Słowacji (KEGA) nr 014UCM-4/2016 pt. „English for Students of Mass Media Communication”.

Słowa kluczowe: duujęzyczność, semikomunikacja, duujęzyczność czesko-słouacka, kontakt językowy, media.

\footnotetext{
${ }^{1}$ Correspondence address: University of Ss. Cyril and Methodius in Trnava, Faculty of Mass Media Communication, Nám. J. Herdu 2, 91701 Trnava, Slovak Republic, e-mail: ahurajova@yahoo.com.

2 This paper/article was prepared as part of the research project supported by the Grant Agency of the Ministry of Education of the Slovak Republic (KEGA) No. 014UCM-4/2016, entitled 'English for Students of Mass Media Communication'.
} 


\section{Introduction}

The decades after the split of former Czechoslovakia in January 1993 introduced new features in the Czech-Slovak language contact, which had not been known before. The contemporary language contact situation is characterised by the fact that also after the split both languages are used among Czechs and Slovaks in a variety of communicative situations, including particular speakers alternating between Czech and Slovak ${ }^{3}$.

This article deals mainly with the issue of Czech-Slovak bilingualism in the media against the background of the political, social and cultural changes that emerged in the Czech and Slovak societies after the split of Czechoslovakia in 1993. Bilingualism is usually analysed in the context of linguistics, psycholinguistics, sociolinguistics, cognitive psychology and neuropsychology, among which predominantly studies aimed at the linguistic analysis of bilingualism. For Sokolová ${ }^{4}$, there are four most prominent categories of bilingualism in Slovakia:

- The bilingualism of Slovaks living abroad needs to be divided into bilingualism in stable Slovak communities abroad (e.g. in Hungary, Romania, currently also in Ireland, and in some cities in the USA and Canada), and bilingualism of individuals and families living abroad outside Slovak-speaking communities.

- The bilingualism of national minorities living in border regions and having historical roots in our region. According to 2011 population census data by the Statistical Office of the Slovak Republic, the inhabitants of the Slovak Republic identify the following languages as their mother tongues: Slovak, Hungarian, Roma, Ruthenian, Ukrainian, Czech, German, Polish, Croatian, Serbian, Russian, Yiddish, Bulgarian, English, French, Spanish, Italian, Arabic, Romanian, Greek, Vietnamese, Albanian, and others. The data also show that when comparing the mother tongue to the most frequently used language in public, the use of the Slovak language in public was even higher by 2.3 percent among the inhabitants who declared Slovak to be their mother tongue. With other languages it is the other way round - the use of the mother tongue in public is lower (expect for the German language). When comparing the mother tongue to the most frequently used language at home, on the other hand, the data show that the use of the Slovak language at home is by 6.8 percent lower among the inhabitants who declared Slovak to be their mother tongue ${ }^{5}$.

\footnotetext{
${ }^{3}$ M. Nábělková, Closely Related Languages in Contact: Czech, Slovak, 'Czechoslovak'[in:] Small and Large Slavic Languages in Contact. International Journal of the Sociology of Language 183, ed. R. Marti, J. Nekvapil, Mouton de Gruyter, Berlin-New York 2007, pp. 53-73, available at: http://wuw.reference-global.com/doi/pdf/10.1515/IJSL.2007.004 (accessed 12.12.2017).

${ }^{4}$ L. Sokolová, Jazyk ako identita: Sociolingvistická identita $v$ životných príbehoch slovenských bilingvistov [in:] Rozvíjanie cudzojazyčných zručností u detí v školskom a v rodinnom prostredí [Developing children's foreign language skills at school and in a family environment]. Proc. of the international conference, Havana, s.r.o., Bratislava 2012, pp. 168-178.

${ }_{5}^{5}$ Slovenská štatistika a demografia [Slovak Statistics and Demography]. A scientific journal. The Statistical Office of the Slovak Republic, Bratislava 2014, vol. 24, no. 3, p. 133, available at: ftp://193.87.31.84/0190640/Slovenska_statistika_a_demografia_3_2014.pdf (accessed 12.11.2017).
} 
- Collective passive Slovak-Czech or Czech-Slovak bilingualism. The language situation in the former Czechoslovakia is really unique. When in one country, citizens used two languages, but while communicating with each other everybody spoke in their own language ${ }^{6}$. This situation is referred to as semi-communication ${ }^{7,8}$, which is actually bilingualism with specific features. Sloboda ${ }^{9}$, however, argues that although the users of Slovak and Czech languages are bilingual, i.e. they have the ability to use two languages in their lives, they speak and write only in one language. They generally do not produce but only receive discourse (i.e. spoken and written texts) in the other (second) language. Horecký ${ }^{10}$ also uses the concept of Czech-Slovak and Slovak-Czech diglossia for the Czech-Slovak language situation, when the basic code (native language) and the second-code (other language) elements coexist in the communication situation. To characterise the specific Czech-Slovak communication, Budovičová ${ }^{11}$ applied the term 'semi-communication', which she defines as incomplete or even defective communication, especially on the content and semantic level.

\section{Semi-communication vs. bilingualism}

In the course of the duration of mutual contacts that are caused by the geographical position of both countries on the one side, the similarity of both languages on the other, and, last but not least, a common state and history, Slovak and Czech interactants created certain rules that identify the elements of discourse of the other language with features of the system of their own language. These rules facilitate a mutual understanding. A so-called interlingual analogy is established between them. It is to say that an expression in the other language discourse corresponds to something in their own language, but the form of the word does not completely match. However, there are also words that would hardly be identified as similar, and these are the words that create a communication barrier between Czechs and Slovaks. Although at the time of functioning of the common state it was taken for granted that Czechs and Slovaks understood each other perfectly and it was also considered ideologically correct not

\footnotetext{
${ }^{6}$ M. Sloboda, Slovensko-česká (semi)komunikace a vzájemná (ne)srozumitelnost, „Čeština doma a ve světe", 2004, vol. 12, no. 3-4, pp. 208-220.

7 J. Horecký, Slovensko-česká diglosná komunikácia [in:] Sociolingvistické aspekty výskumu súčasnej slovenčiny. Sociolingvistica Slovaca 1, ed. S. Ondrejovič, M. Šimková, VEDA, Bratislava 1995, p. 183.

8 J. Dolník, Der slowakisch-tschechische Bilingualismus [in:] Bilingvizmus. Minulost', prítomnost', budúcnost'. ed. J. Štefánik, Academic Electronic Press, Bratislava 2002, pp. 37-42.

${ }_{9}$ M. Sloboda, Slovensko-česká (semi)komunikace a vzájemná (ne)srozumitelnost, op. cit.

10 J. Horeckú, Slovensko-česká diglosná komunikácia, op. cit.

${ }^{11}$ V. Budovičová, Semikomunikácia ako faktor medzijazykovej dynamiky [Semicommunication as a factor of interlingual dynamics] [in:] Dynamika současné čestiny z hlediska linguistické teorie a školské praxe, ed. R. Brabcová, F. Šícha, Univerzita Karlova, Praha 1988, pp. $45-54$.
} 
to point out the differences between these tuo languages, after the split of Czechoslovakia and the emergence of two independent republics these communication differences have become more apparent over the years. The problems in communication are due to insufficient knowledge of the other language. Such a problematic relationship is well described by the term 'semi-communication'. Semi-communication describes communication problems in contacts between Czech and Slovak ${ }^{12,13,14}$.

Czech and Slovak interactants can easily communicate with each other as long as the words that appear in the communication are similar. As soon as completely different words are used, communication problems arise. At the same time, there are words in both languages that sound very similar but have different meanings.

Czech-Slovak bilingualism is a special kind of bilingualism and this is on account of the overall long-standing common, close historical and linguistic life and structural similarity of the languages. Obviously, we can talk about societal bilingualism in the former common state in which the social sphere was split between the two languages - everybody spoke their own language, either Czech or Slovak - but the use of languages was not divided functionally, i.e. in communication situations. The Czech language prevailed in Bohemia and the Slovak language in Slovakia.

Another specific feature of Czech-Slovak bilingualism is bivalence. In many cases, there are expressions that can be classified as belonging to both languages. Therefore, written e-mail correspondence is much harder to analyse as it often lacks diacritics, thus further enhancing bivalence.

Just as in the case of definitions, there are many divisions of bilingualism. In the literature devoted to bilingualism, more kinds of bilingualism are mentioned depending on the point of view taken into account and chosen. A major distinction of the types of bilingualism is that some typologies try to focus their explanation of the second-language acquisition on an individual and others on a societal level. Bilingualism in each country has its own specific peculiarities. Namely, Czech-Slovak bilingualism represents a special kind of bilingualism, which has its own specific features determined by the long-lasting common historical, linguistic and cultural coexistence in one state. Therefore, Czech-Slovak bilingualism can be labelled as social bilingualism in a common state.

According to Nábělková ${ }^{15}$, in the forms of Czech-Slovak bilingualism two framework contradictions can be considered, which are normally attributable to the issue of bilingualism as such. These are the dichotomies - individual and perceptive (receptive, passive) - productive (active) bilingualism. In the context of Czech-Slovak bilingualism, attention is being paid especially to passive bilingualism. Nábělková, houever, argues

\footnotetext{
12 J. Dolník, Der slowakisch-tschechische Bilingualismus, op. cit.

13 J. Horecký, Slovensko-česká diglosná komunikácia, op. cit.

14 J. Dolník, Der slowakisch-tschechische Bilingualismus, op. cit.

${ }^{15}$ M. Nábělková, Slovenčina a čeština v kontakte. Pokračovanie príbehu, Vydavatel'stvo SAV, Jazykovedný ústav L. Štúra SAV - Filozofická fakulta Univerzity Karlovy v Praze, VEDA, Bratislava-Praha 2008.
} 
that in addition to the term 'passive bilingualism', the more appropriately motivated term 'perceptive bilingualism' should be applied, since in Czech-Slovak communication the users' attitude to communication is not passive but it is an active perception process.

When speaking about the uniqueness of the Czech-Slovak lingual co-existence, it can be perceived against the background of the comparable relations of other languages. The mutual intelligibility of Czech and Slovak and the related possibility of bilingual communication without targeted language training, as observed in Czech-Slovak language relations, is one of the characteristics of the communication practice of other pairs or groups of languages in Europe. These are, for example, Slavic languages, such as Croatian, Serbian, Bosnian; Bulgarian, Macedonian; Russian, Ukrainian; Russian, Belarusian. Haugen ${ }^{16}$ describes the semi-communication in the Scandinavian states of Denmark, Norway and Sweden. It is, however, worth noting that there is a mutual lack of knowledge of the languages, as well as cultures.

\section{The language situation in former Czechoslovakia}

Throughout the existence of former Czechoslovakia, mutual cultural relations were being examined on the basis of the then language situation, which was characterised by the particularity of interlingual relations. The Czech and Slovak languages were acting as two independent and equal languages of one state, and were fulfilling the function of social communication means not only in their natural environment but they were also serving as means of national communication. Means of mass communication such as TV, radio, film and the press are characterised by semi-communication, i.e. alternating both languages in national political, cultural and sports events, or the broadcasting of some programmes in Czech or Slovak to the whole country ${ }^{17}$.

Throughout the existence of a common state, Czechs and Slovaks kept in touch with both languages, with these alternating in the media, for example when watching bilingual Czech-Slovak news, music and sports programmes, performances of various artists on TV, watching films, listening to songs, reading articles in magazines and newspapers, and so on. In the Czech environment, for example, Slovak TV series and Slovak dubbed films used to have a high viewer rating. In general, such bilingualism with Czech and Slovak, especially in the news, sports or entertainment on Czechoslovak radio and television, was widely accepted. Since early childhood people were getting accustomed to the fact that perception of information and watching also intellectually more demanding programmes did not cause any difficulties, and sometimes they did not even fully realise the alternation of the languages. A mutual affinity was being developed through long-term habits since a young age, which is when an individual

${ }_{16}$ E. Haugen, Semicommunication. The Language Gap in Scandinavian [in:] E. Haugen, The Ecology of Language, Stanford University Press, Stanford 1972, pp. 215-236.

${ }_{17}$ J. Horecký, Všeobecné a špecifické črty jazykovej kultúry v našich jazykoch [in:] Aktuální otázky jazykové kultury v socialistické společnosti, ed. J. Chaloupek, Academia, Praha 1979, pp. 21-24. 
is most receptive. In addition to school where the other language was also represented, means of mass communication performed an educational role as well.

The following features characterised Czechoslovakia and Czecho-Slovakia before the split:

1. declared equality of both languages;

2. federal broadcasting - alternation of languages in the media;

3. intensified communication to receive utterances in Slovak on the Czech side as compared to the previous time;

4. intensification of the Czechoslovak literary context, common professional context;

5. communication coexistence of Czech and Slovak when Czechs and Slovaks are engaged in mutual discourse and everyone speaks their oun language.

Slovak in the Czech environment and Czech in the Slovak environment were accepted as 'generally intelligible languages' ${ }^{18}$.

\section{The Czech and Slovak languages today}

Slovaks represent the most numerous national minority in the Czech Republic. They are dispersed across the whole territory of the Czech Republic as an inconsistent but ethnically open group. Slovaks living in the Czech Republic do not behave like other Slovaks living abroad or like any other minority in the Czech Republic. They integrate easily in the Czech majority society. Territorial, cultural and linguistic proximity as well as common history have caused that many Slovaks do not consider the Czech culture as foreign and have a positive attitude towards the Czech society, which is evident from the high degree of integration and a strong assimilation tendency. From the point of view of linguistic inclusion, Slovak language bearers can be divided into two groups that differ in status and communication habits - the so-called 'Czech Slovaks' belonging to the Slovak minority and the 'Slovak Slovaks' living in the Czech Republic in the short or the long term. The group of 'Slovak Slovaks' living in the Czech Republic also includes Slovak students studying at Czech universities. According to available data, approximately 22,500 students from Slovakia were studying at universities in the Czech Republic in $2016^{19}$.

The change of status of Slovaks in the Czech Republic after the split of the common state has brought about a change of status of the Slovak language. Unlike in the previous period, the Slovak language does not appear to be one of two equal languages, but within the Czech Republic it has officially become a minority language. By splitting the common state into two independent states, a system change in the language situation emerged - an extinction of tuo-sided semi-communication ${ }^{20}$. Similarly, also the position

\footnotetext{
${ }^{18}$ M. Nábělková, Slovenčina a čeština $v$ kontakte, op. cit.

19 J. Horáková, Čo láka slovenských študentov na české univerzity, available at: http://vysokeskoly.sme.sk/c/8309181/co-laka-slovenskych-studentov-na-ceske-univerzity.html (accessed 12.11.2017).

${ }^{20}$ M. Nábělková, Slovenčina a čeština $v$ kontakte, op. cit.
} 
of the Czech language in the Slovak Republic has changed, with Czech moving towards a position of a minority language on the territory of the Slovak Republic. However, contact with the other language in mutual understanding involves and develops a certain level of perceptive bilingualism.

In this new situation of two separate states with the disappearance of regular federal bilingualism, contacts of one language with the other have weakened in terms of the Slovak language in the Czech environment. This newly-appeared situation is characterised by anticipation of a divergence of the two languages, i.e. a weakening ability to communicate in the other, non-mother tongue. In terms of these two mutually intelligible languages, by the term 'to communicate' we essentially mean 'to understand' and 'to receive'; therefore, it can be argued that the divergence of the two languages mainly concerns the level of passive bilingualism.

\section{Divergence of the languages}

The divergence of Czech and Slovak is characterised by a certain inequality and asymmetry that is particularly evident in the offer of cultural production in both states. In the Czech media environment Slovak appears to a much lesser extent, the broadcasting of programmes in the Slovak language, original or dubbed films is relatively rare. The limitation of contacts with original Slovak cultural production in various areas has caused a limitation of contacts with the Slovak language, which brings about a change in terms of the intelligibility of Slovak for Czech citizens. On the other hand, in the Slovak environment, contacts with cultural production in Czech are not restricted - on the contrary, the situation in Slovakia is characterised by the wide availability of Czech books, Czech book translations of foreign authors, numerous Czech and Czech-dubbed programmes appear on TV, etc. Slovaks normally read Czech periodicals and books, watch Czech TV stations and films, listen to Czech music, etc. Here the situation is as it was already in the past, namely that Slovaks have more frequent contact with the Czech language than Czechs with the Slovak language.

In terms of the issue of language divergence, a difficult question of (un)intelligibility of the Slovak language for Czech children arises. In general, there is a prevailing vieu that Czech children 'already' do not understand Slovak. Compared to the previous period, Czech children have contact with the Slovak language and Slovak texts to a much lesser extent, while in Slovakia children have contact with the Czech language mostly on account of its presence in the media. Overall, the fading bilingualism can be mainly attributed to the Czech Republic.

Some sociolinguists ${ }^{21,22}$ argue that not only political changes, but also age differences can be seen as indicators of linguistic change. According to a study carried out by

${ }^{21}$ R. Mesthrie, J. Swann, A. Deumert, W.L. Leap, Introducing Sociolinguistics, Edinburgh UP, Edinburgh 2009.

${ }^{22}$ R. Pavlík, Elements of Sociolinguistics, Univerzita Komenského v Bratislave, Bratislava 2006. 
Dickens in 2009, 90\% of Czechs at the age of 15 and above claimed to have a passive knowledge of the Slovak language. The generations aged above 30 and 40, who grew up in former Czechoslovakia, reported a high level of knowledge of Slovak. The least knowledge of the Slovak language was reported by the youngest generation born after the split of Czechoslovakia ${ }^{23}$.

To conclude, the political change caused a massive language shift mainly in Slovakia, which caused the younger Czech generation to struggle with understanding the Slovak language. Furthermore, both politics and age differences have played a key role in the fading bilingualism among Czechs. The future of perceptive bilingualism of Czechs can now be seen more positively on account of bilingual media and Slovak migrants ${ }^{24}$.

\section{Cultural exchange and the Slovak language in the Czech environment - television}

As mentioned above, television belongs to the media in which the presence of Slovak programmes (or programmes in Slovak) has been limited after the split of the common state, and attempts to set up broadcasting for the Slovak minority failed. It is generally known that it was television that used to be the most important source of the Slovak language for the Czech youth.

Currently, viewers in both states can choose programmes in the other language on their own TV channels; there is also the possibility to watch TV channels of the other language community thanks to satellite broadcasting and cable television, which also offers channels with programmes and films alternating Czech and Slovak, e.g. Hallmark, Discovery, Galaxie Sport. In addition, Czech Television and Czech commercial TV channels offer entertainment programmes in which guests from the Slovak cultural environment appear and communicate in Slovak (e.g. Všechnopárty, Show Jana Krause, Na plovárně). The Slovak language is also present in programmes hosted by Slovak presenters, such as the recently widely popular Czech-Slovak Superstar or Czecho-Slovakia's Got Talent, which have the highest viewer rating among the youth. What is interesting, however, is the idea of Czechoslovak cooperation and the idea to hire presenters and/or TV show judges from both countries, with each of them speaking their own language. Here it is assumed that young viewers have trouble understanding. Hence, in certain situations, a presenter - either alone or with a partner - tries to translate or explain a foreign-language phenomenon.

\footnotetext{
${ }^{23}$ M. Sloboda, M. Nábělková, Receptive Multilingualism in 'monolingual' Media: Managing the Presence of Slovak on Czech Websites, „International Journal of Multilingualism” 2013, vol. 10, no. 2, pp. 196-213.

${ }^{24}$ L. Zhengová, The implications on Czech and Slovak bilingualism after the split of Czechoslovakia, available at: https://prezi.com/dzj4bi-jte23/the-implications-on-czechand-slovak-bilingualism-after-the/ (accessed 12.11.2017).
} 
In recent years, there has been an interesting phenomenon of the broadcasting of a Czech TV series in the Czech environment in which also Slovak actors appear. They perform either in Slovak or Czech, or they are dubbed into Czech. The practice of a mutual performance of Slovak and Czech actors in films naturally spread throughout the existence of the common state; however, even today there are many Czech TV series and films in which Slovak actors appear.

\section{Cultural exchange and the Slovak language in the Czech environment - radio}

Modern popular music is currently one of the most distinctive types of popular art. Through the mass media, music reaches wide audiences. The Slovak music scene is currently presented in the media, not only on TV or the radio, but also magazines contain texts dealing with Slovak music or musicians. The popularity of many successful Slovak music bands known from the Czechoslovak era still persists, e.g. Elán, Team, Miroslav Žbirka, etc. At the same time, new music bands and performers appear who reached their audiences in the Czech cultural environment. Slovak musical production and musical performance is ranked in the first places of some Czecho-Slovak radio charts.

The Czech Radio broadcasts programmes for Slovak citizens. The aim of such programmes is to spread the history and culture from different areas among its listeners; also discussions with Slovak personalities regularly take place. In 2006 Radio Spin was established in Prague, which broadcasts in the Slovak language not only for Slovaks. In the Czech Radio broadcasting Slovak radio speakers are also allowed to present.

\section{Cultural exchange and the Slovak language in the Czech environment - literature, cultural clubs and magazines}

In terms of the presence of books of Slovak authors in the Czech literary environment, it can be concluded that the situation has clearly changed over the last decades. Nábělková $^{25}$ describes a significant change compared to the previous years - re-translating of Slovak literature into Czech, with the number of translations tending to increase. The situation in Slovakia is different; there are book translations into Czech as well as Czech books that are not translated. However, this is not only the question of language, as the preferences of publishers as well as economic issues are also taken into account.

As was already mentioned before, after 1993 Slovaks became the most numerous minority in the Czech Republic. The institutions of the Slovak minority in the Czech Republic cooperate largely in organising Slovak cultural events on Czech territory. Among the most important events are the Days of Slovak Culture in the Czech

${ }^{25}$ M. Nábělková, Slovenčina a čeština v kontakte, op. cit. 
Republic, the Slovak Ball, the Czechoslovak Ball. Periodicals published with the support of the Government of the Czech Republic inform about cultural events in Slovakia and Slovaks in the Czech Republic. There are three Slovak monthly magazines which can be described as cultural and social magazines: Korene, Dotyky, Slovenské listy ${ }^{26}$.

\section{Conclusion}

The mapping of cultural, social and political life as well as cooperation in different areas in print, on TV and the radio shous - though it is sometimes not obvious in common reflection - diverse and intense Czecho-Slovak cultural contacts.

\section{Bibliography}

Budovičová V., Semikomunikácia ako faktor medzijazykovej dynamiky [Semi-communication as a factor of interlingual dynamics] [in:] Dynamika současné čestiny z hlediska linguistické teorie a školské praxe, ed. R. Brabcová, F. Štícha, Univerzita Karlova, Praha 1988.

Dolník J., Der slowakisch-tschechische Bilingualismus [in:] Bilingvizmus. Minulost', prítomnost', budúcnost', ed. J. Štefánik, Academic Electronic Press, Bratislava 2002.

Haugen E., Semicommunication. The Language Gap in Scandinavian [in:] E. Haugen, The Ecology of Language, Stanford University Press, Stanford 1972.

Horáková J., Čo láka slovenských študentov na české univerzity, available at: http://vysokeskoly.sme.sk/c/8309181/co-laka-slovenskych-studentov-na-ceske-univerzity.html (accessed 12.12.2017).

Horecký J., Slovensko-česká diglosná komunikácia [in:] Sociolingvistické aspekty výskumu súčasnej slovenčiny. Sociolingvistica Slovaca 1, ed. S. Ondrejovič, M. Šimková, VEDA, Bratislava 1995.

Horecký J., Všeobecné a špecifické črty jazykovej kultúry v našich jazykoch [in:] Aktuální otázky jazykové kultury v socialistické společnosti, ed. J. Chaloupek, Academia, Praha 1979.

Juza M., Krajanská tlač - poznáme ju?, 'Otázky žurnalistiky' 2000, no. 4.

Mesthrie R., Swann J., Deumert A., Leap W.L., Introducing Sociolinguistics, Edinburgh UP, Edinburgh 2009.

Nábělková M., Closely Related Languages in Contact: Czech, Slovak,Czechoslovak [in:] Small and Large Slavic Languages in Contact. International Journal of the Sociology of Language 183, ed. R. Marti, J. Nekvapil, Mouton de Gruyter, Berlin-New York 2007, available at: http://wuw.reference-global.com/doi/pdf/10.1515/IJSL.2007.004 (accessed 12.12.2017).

Nábělková M., Slovenčina a čeština v kontakte. Pokračovanie príbehu. Vydavatel'stvo SAV, Jazykovednú ústav L. Štúra SAV- Filozofická fakulta Univerzity Karlovy v Praze, VEDA, Bratislava-Praha 2008.

Pavlík R., Elements of Sociolinguistics. Univerzita Komenského v Bratislave, Bratislava 2006.

Sloboda M., Slovensko-česká (semi)komunikace a vzájemná (ne)srozumitelnost, "In Čeština doma a ve světe" 2004, vol. 12, no. 3-4.

${ }^{26}$ M. Juza, Krajanská tlač - poznáme ju?, „Otázky žurnalistiky” 2000, no. 4, pp. 336-340. 
Sloboda M., Nábělková M., Receptive Multilingualism in 'monolingual' Media: Managing the Presence of Slovak on Czech Websites, "International Journal of Multilingualism", 2013, vol. 10, no. 2.

Slovenská štatistika a demografia [Slovak Statistics and Demography]. A scientific journal. The Statistical Office of the Slovak Republic, Bratislava 2014, vol. 24, no. 3, p. 133, available at: ftp://193.87.31.84/0190640/Slovenska_statistika_a_demografia_3_2014.pdf (accessed 12.11.2017).

Sokolová L., Jazyk ako identita: Sociolingvistická identita v životných príbehoch slovenských bilingvistov [in:] Rozvíjanie cudzojazyčných zručností u detí v školskom a v rodinnom prostredí [Developing children's foreign language skills at school and in a family environment]. Proc. of the international conference. Havana, s.r.o., Bratislava 2012.

Zhengová L., The implications on Czech and Slovak bilingualism after the split of Czechoslovakia, available at: https://prezi.com/dzj4bi-jte23/the-implications-on-czech-and-slovakbilingualism-after-the/ (accessed 12.12.2017). 